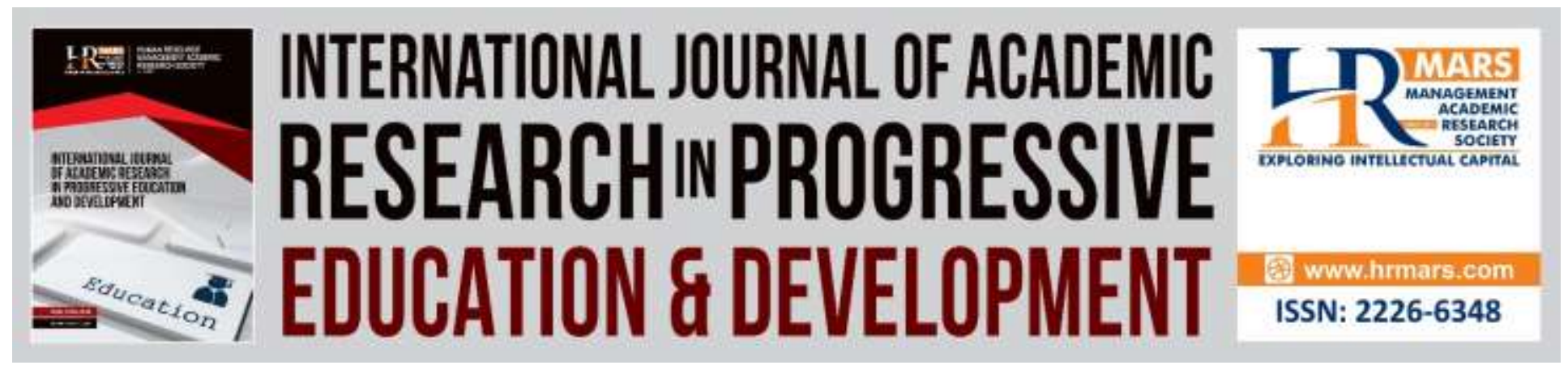

\title{
A Descriptive Analysis of Intercultural Content of the EFL Textbooks Used in the Intermediate Schools in Iraq
}

\author{
Ali Abdulridha Obaid, Lilliati Ismail, Abu Bakar Razali, Nor Shahila Mansor
}

To Link this Article: http://dx.doi.org/10.6007/IJARPED/v8-i4/6697

DOI:10.6007/IJARPED/v8-i4/6697

Received: 10 October 2019, Revised: 25 October 2019, Accepted: 15 November 2019

Published Online: 30 November 2019

In-Text Citation: (Obaid, Ismail, Razali, \& Mansor, 2019)

To Cite this Article: Obaid, A. A., Ismail, L., Razali, A. B., \& Mansor, N. S. (2019). A Descriptive Analysis of Intercultural Content of the Efl Textbooks Used in the Intermediate Schools in Iraq. International Journal of Academic Research in Progressive Education and Development, 8(4), 738-756.

Copyright: (C) 2019 The Author(s)

Published by Human Resource Management Academic Research Society (www.hrmars.com)

This article is published under the Creative Commons Attribution (CC BY 4.0) license. Anyone may reproduce, distribute, translate and create derivative works of this article (for both commercial and non-commercial purposes), subject to full attribution to the original publication and authors. The full terms of this license may be seen

at: http://creativecommons.org/licences/by/4.0/legalcode

\section{Vol. 8(4) 2019, Pg. 738 - 756}

http://hrmars.com/index.php/pages/detail/IJARPED

JOURNAL HOMEPAGE

Full Terms \& Conditions of access and use can be found at http://hrmars.com/index.php/pages/detail/publication-ethics 


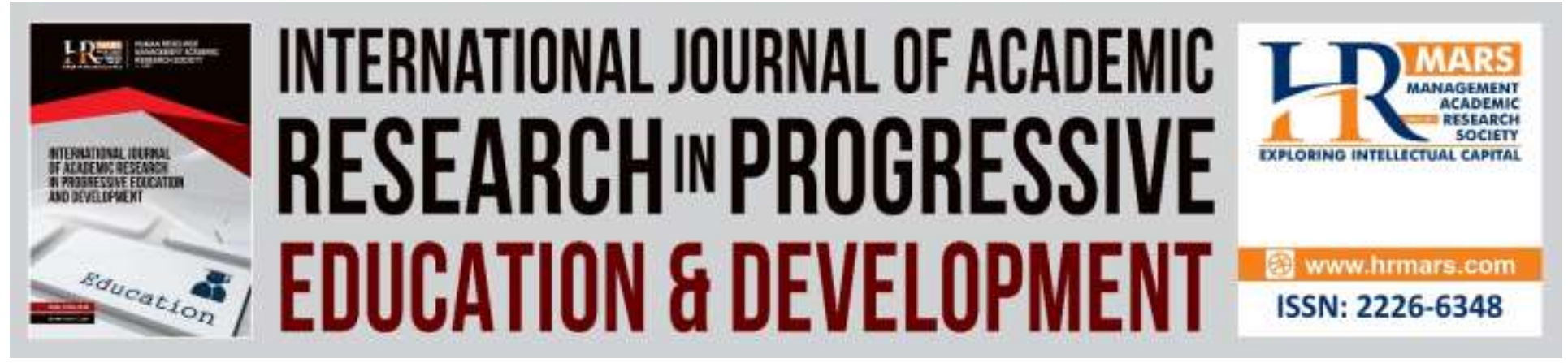

\title{
A Descriptive Analysis of Intercultural Content of the EFL Textbooks Used in the Intermediate Schools in Iraq
}

\author{
Ali Abdulridha Obaid, Lilliati Ismail, Abu Bakar Razali \\ Faculty of Educational Studies, Universiti Putra Malaysia (UPM), Serdang, Selangor, Malaysia \\ Nor Shahila Mansor \\ Faculty of Modern Languages and Communication, Universiti Putra Malaysia (UPM) \\ Serdang, Selangor, Malaysia
}

\begin{abstract}
Integrating culture in ELT, particularly in EFL textbooks, has recently gained greater importance and attention based on both the sociocultural theory that portraits learning as a social action, and the conception that culture and language are unavoidably attached. It has also come to be more important because English is an international language and a lingua Franca in the twentyfirst era of globalization. Accordingly, new orientations in ELT have arisen such as improving the intercultural competence. Since 2012, Iraq have adopted "English for Iraq" (EFI) series of textbooks which seem to lack orientations towards intercultural competence. This paper aims at finding out how the intercultural materials of EFI textbook are presented and whether they develop the Iraqi learners' intercultural competence. Based on an adapted version of Byram's (1997) model, a descriptive content analysis is utilized to examine the texts and visuals in the three textbooks used in intermediate schools. Findings indicate that intercultural elements in the textbooks show sharp differences in their frequency of occurrences portraying an imbalanced intercultural presentation with a knowledge-oriented majority of mainly fact-stating materials. As such, the authors found that these textbooks do not improve the Iraqi EFL learners' intercultural competence. The paper has educational implications in concern of reconsidering culture integration in the Iraqi EFL textbooks so as to cope with the recent trends and objectives in ELT to promote the students' empathy, tolerance, and respect of otherness.

Keywords: Textbook Analysis, Intercultural Competence, English as Lingua Franca, Culture Integration.
\end{abstract}

\section{Introduction}

Integrating culture in English language teaching has come to be more in focus due to English being an international language (EIL) and a lingua Franca (ELF) dominating various fields of 
knowledge as well as everyday life practices in most countries of the world. Therefore, several trends and concepts have promptly received greater interest in TEFL and TESL literature, such as intercultural communicative competence, intercultural education, intercultural literacy, intercultural awareness, and intercultural sensitivity. As a result, more objectives in ELT have emerged such as promoting the learners' intercultural competence to qualify them to be efficient intercultural speakers characterized with tolerance, empathy and respect of otherness. Educationalists, as Kramsch (2013) suggests, would think more of developing the learners' "intercultural competence that would shortchange neither their own culture nor the target culture, but would make them into cultural mediators in a globalized world" (P: 57), and that would be "steeped in a deep understanding of their historicity and subjectivity as language" (ibid: 60). In Europe, for instance, criteria were set (see CEFR, 2011) as standards for producing EFL textbooks which should promote the learners' intercultural communicative competence through providing materials that develop knowledge, attitude, skills and cultural awareness.

A large number of EFL textbooks are continuously published as writers take into account new developments in the ELT field. But, producing a perfect textbook that can work in all cases and overcome all the expected problems in a specific setting is a matter that has been viewed as too ideal by the specialists in the ELT area. Grant (1987: 8) plainly puts it "Perfect book does not exist". Hence, textbooks' contents, including the cultural / intercultural representations, need to be consistently examined for the purposes of evaluation or improvement. Studies regarding textbooks, particularly in-use textbooks, are periodically conducted to fine-tune these contents. In Iraq, the (EFI) textbooks series is the sole source of knowledge of learning English in schools. For each of the three grades in intermediate schools there is a Students' textbook, Activity book, Teachers' guide in addition to Audio materials. This series has been used since 2012 in all schools whether public or private. These textbooks are written by foreign authors (Terry O'Neill \& Peter Snow) and published by Garnet Education (2017). Foreign writers are usually not familiar with the learners' local culture, consequently, they are not expected to represent the local culture in relation to other foreign cultures to promote intercultuality in textbooks' materials. However, the series of EFI textbooks has not been so far examined with a lot of quality studies in the available literature in terms of its intercultural load. To the best knowledge of the researcher, there are a few studies, such as Al-Akraa (2013) and Obaidi (2015), which address the cultural content of the textbooks in an evaluating sense with little reference to intercultural representations. Therefore, there generally remains a literature gap that also raise a need to quality studies for scrutinizing the intercultural content of these textbooks for different purposes like the textbooks' conformity to the new trends in ELT, including interculturality.

In the 21st-century where English has become a lingua franca that can meet the needs of its users for communicating not only globally but even locally (McKay, 2002: 24; Okoye, Ugochukwu, Chidoziem, (2018), the intercultural dimension has gained an utmost priority within the objectives and practices connected to culture integration in the ELT textbooks in the context of different countries of the world. As a result, one of the objectives globally set for EFL textbooks is promoting the learners' intercultural competence. In Iraq, EFI textbooks' series also needs to be investigated in relation to their intercultural load which is supposed to develop the learners' intercultural competence. 
Based on this argument, the rationale of the current study is motivated by the consistent need to explore the hidden curriculum of the textbooks' language content in relation to the intercultural dimension essential for promoting the learners' intercultural competence. The study is then intended to scrutinize the hidden curriculum in the content of EFI textbook series in the three intermediate-school textbooks, more specifically, examining the intercultural representations in this series to find out whether they are introduced with sharp difference in their frequency occurrences leading to an imbalanced intercultural content, and whether the students can consequently be expected to develop their intercultural competence and be wellprepared as intercultural citizens successfully communicating in intercultural situations with tolerance, empathy and respect of otherness. The following research questions are to be answered:

1. How are the intercultural elements (knowledge, attitude, and skills) represented in the written texts and the visuals of "English for Iraq" textbooks currently used in intermediate schools in Iraq?

2. To what extent does the intermediate school "English for Iraq" textbooks' content develop the learners' intercultural competence through integrating intercultural representations?

This paper is limited to examining the written texts and the visuals in the three student's books and their counterpart activity books of the intermediate schools. Audio materials are mostly repeating the written materials. It has important implications in concern of the importance of culture integration in the Iraqi EFL context, particularly interculturality in EFI textbooks.

\section{Sociocultural Theory and Review of Past Studies}

The core premise of the socio-cultural theory about the human learning, initially proposed by Lev Vygotsky (1978), is that individual's cognitive development and learning, including language learning, occurs through social interaction which can also take place in instructional settings. In a practical perspective, Lantolf, Thorne, \& Poehner (2015: 207) explains that the "developmental processes take place through participation in cultural, linguistic, and historically formed settings" (P: 2017); these settings are formed in various manifestations such as peer group interaction, family life, or workplaces, to mention but a few. Second language learners are expected, according to this theory, to deal with cultural aspects, practice more interactions (which can be simulated in classes), and engage in group work and peers in their schooling activities. As related to textbooks, materials can provide learners with opportunities encouraging them to interact with interlocutors from their own culture and from other (foreign) cultures. Shrum and Glisan (2009) refer to the learners' need for knowing the socio-cultural factors which affect communication; this need is for the "knowledge of how to use language to express their ideas and intent (attitudes), and knowledge of strategies for how to communicate with others" (P: 14). In interactional participation in a social activity in communication, the cultural aspect is a key factor. For a citizen in the twenty-first century era of globalization, the intercultural aspect comes to be another key factor. 
The cultural and intercultural components help learners raise the cultural awareness, develop feelings of tolerance and empathy, show respect to counterpart cultures in communications, broaden the perspectives, and encourage appreciating the differences and similarities among cultures (see Larzen-Ostermark, 2008 and Casto, Sercu \& Garcia, 2004). Méndez García (2005) believes that using the target language culture in intercultural communication materials serves different purposes, namely, enhancing students' knowledge of the world, familiarizing the learners with the most salient behavioral patterns of the target societies, promoting attitudes of respect and tolerance, and emphasizing the relative role of one's cultural assumptions or developing real intercultural communication in an intercultural world.

Drawing upon Hatoss' (2004) checklist which is more concerned with intercultural elements, Tozun's (2012) examined the intercultural aspects in the textbooks adopted by secondary schools in Cyprus. The findings indicate that materials of the textbooks do not sufficiently cater for the intercultural dimension nor do they, as a result, develop intercultural sensitivity, and the teachers are aware of the importance of teaching culture but do not have a clear idea about the intercultural dimension of language teaching. Eva Reid (2015) wrote about the techniques that can improve the intercultural communicative competence in EFL classes. These techniques such as comparison method, drama, cultural island, cultural assimilation, cultural capsule, reformulation, field trip, role plays, songs, portfolio, prediction, research, and games, are to be applied from the start of the education process and for all ages. They feed the learners with knowledge, attitudes, skills as well as awareness of the source culture and target culture in addition to other cultures (P: 940).

\section{Byram (1997) Model of Intercultural Communicative Competence (ICC)}

One of the world-wide known theories illustrating the intercultural dimension in language teaching is Byram's (1997) intercultural communicative competence (ICC) model in language teaching, which is adopted in the CEFR (The Common European Framework of Reference for Languages) international standards of quality EFL textbooks as part of the European standards for the quality of textbooks in concern of the intercultural dimension. Byram's (1997) proposed a comprehensive model for ICC, with a new orientation of emphasizing the learner's source culture, language, and social identity as having serious impact on acquiring his/her intercultural interaction (p. 3). For intercultural communicative competence (ICC) to be fulfilled, four competencies are to be developed linguistic, sociolinguistic, discourse, and intercultural competence (IC).

Byram's (1997, 2009, 2002) conception of developing the intercultural communicative competence is based on a thesis that the ultimate target of the intercultural approach in language teaching is not, on the part of the learner, acquiring the native-speaker competence but developing the intercultural communicative competence (see also Guilherme, 2002). Accordingly, achieving the communicative competence through developing the four language skills (reading, listening, writing and speaking) is no longer an aim in itself but culture is to be integrated (particularly in textbooks) to develop intercultural competence for successful interaction and communication.

The intercultural competence (IC) is, then, an essential part of the Byram's overall conception and scheme of ICC. The scheme involves five elements (ibid: $57-64$ ) with a group of objectives 
in each. They are attitude (savoir etre) that is mainly a case of expressing oneself with curiosity and open-mindedness to other cultures; so, it covers terms like empathy, otherness, tolerance and culture sensitivity. For language learners, this expresses the desire to question their own culture and other cultures; in classroom activities, in order to avoid reinforcing possible prejudices and stereotypes, similarities between cultures and not differences can be focused on first. The second element is knowledge (savoir) which is the sociocultural knowledge necessary to overcome any critical cultural communicative challenge through changing beliefs, attitudes, values and behaviors. The third element is skills of interpreting and relating (savoir comprendre) in which learners are exposed to tasks of working with documents which provide opportunities to first analyze cultures transferred to them in documents of literature or any other kind of text and life events, and to explain these cultures and relate them to documents from their own culture. The fourth element is skills of discovery and interaction (savoir apprendre / faire) in which the learner gains more cultural knowledge and practice and is able to put all skills, attitudes and knowledge into action in real-life interaction. The fifth and the last element is critical cultural awareness (savoir s'engager) which represents the target of the intercultural learning; in this element a learner is expected to perceive and, in a critical sense, evaluate aspects of his/her own culture and the other cultures in order to develop acceptance and tolerance in a supposedly actual intercultural sensitive environment.

\section{Research Methodology}

The qualitative method of research is conducted to analyze documents as related to their intercultural content with an adapted theory-based scheme of analysis.

Textbooks, as published documents, are considered significant components in the teaching/learning process not only because of "the way in which they present prescribed information but also for their projection of approved values and ideologies" (McCulloch, 2004: 67). The firsthand data is the written texts and the visuals in the three intermediate student's books and their encounter activity books. Each of the three investigated textbooks contain eight units. Each unit consists of almost ten lessons. Total units will be twenty-four units.

The content of the textbooks under study is analyzed for meaning elicitation related to intercultural representations, whether the meaning is "a literal or face value meaning" (Ahmed, 2010: 5) or "underlying meaning" (Merriam, 2009: 2). Integration of interculturality in the materials' representations are examined in terms of knowledge, attitude and skills elements. The data collected from documents is usually "organized into major themes, categories and case examples through content analysis" (Labuschagne, 2003: 101).

A descriptive deductive content analysis technique is employed. The unit of analysis is all the themes that refer to the concepts in the analysis scheme whether the theme is demonstrated in a word, sentence, phrase, passage or any meaningful unit of a text or a visual. Generally, a deductive content analysis study always necessitates three main stages which are preparation, categorization, and reporting (see Ezzy, 2002: 83, Cohen et al., $2007: 476-483$ ). But Zhang and Wildemuth (2009: 308 - 19) introduced a comprehensive and more practical sketch of eight steps to be followed in a deductive content analysis study, applicable and appropriate to the purpose of the current study. These steps are preparation of data, specification of analysis unit, specification of categories and the scheme of coding, testing the codes (validity procedures), 
coding the text, checking the coding consistency (e.g. through repeating and revisiting coding), drawing of conclusions, and finally reporting (ibid: $107-115$ ). It is also worth mentioning that this study may contain quantifications in its results but it is still regarded qualitative due to a fact that it is normal to quantify the categories since frequency surveys for categorizations seems inevitable in a content analysis study (Titscher et al, 2000: 55).

The analysis scheme is a checklist for the frequency occurrences of the intercultural representations in the texts and visuals of the textbooks under investigation. It is an adaption of Byram (1997) model representing his conceptualization of the intercultural competence (IC) as part of the intercultural communicative competence (ICC). Byram's (1997) intercultural model consists of five elements (saviors), each of which has its own objectives that can be illustrated in materials for language teaching (see 2 above). For the purpose of this study, the fifth element, critical cultural awareness / political education (savoir s'engager), is excluded because it involves a critical and evaluative sense in which all the individual's knowledge, attitudes, skills are to be operated; therefore, it sums up all the other four elements to be used by the interlocutor with assessing sense and consequently overlaps with them in the analysis process. Then, this element seems to require from the learners to actually engage in real-life situations in order to practice their intercultural competence, awareness and critical abilities.

The checklist for analysis then encompasses only four intercultural elements, namely, the knowledge of cultures, attitudes towards cultures, skills of interpreting and relating cultural element, and skills of discovery and intercultural interaction elements. Table (1) below describes materials' representations for the objectives of each element. Validity of the checklist is obtained by a panel of four experts (university profs) whereas reliability is gained through a pilot study with a peer researcher to find consistency in analysis results for three units randomly selected, one from each textbook. Frequency occurrences of the concepts coded in the checklist are counted in every unit for the intercultural representations. The results are documented on Excel Sheets. 
INTERNATIONAL JOURNAL OF ACADEMIC RESEARCH IN PROGRESSIVE EDUCATION AND DEVELOPMENT

Vol. 8, No. 4, 2019, E-ISSN: 2226-6348 @ 2019 HRMARS

Table (1) Description of objectives of the intercultural elements

\begin{tabular}{|c|c|c|}
\hline $\begin{array}{l}\text { Intercultural } \\
\text { Elements }\end{array}$ & Objectives & Description \\
\hline \multirow{2}{*}{$\begin{array}{l}\text { Knowledge of } \\
\text { cultures }\end{array}$} & Factual knowledge of Cultures & $\begin{array}{l}\text { Materials that increase the learners' knowledge } \\
\text { about culture with providing information and } \\
\text { facts in textbooks }\end{array}$ \\
\hline & Understanding the concept of culture & $\begin{array}{l}\text { Materials that increase the learners' knowledge } \\
\text { about the way culture is defined. }\end{array}$ \\
\hline \multirow{2}{*}{$\begin{array}{l}\text { Attitudes } \\
\text { towards } \\
\text { Cultures }\end{array}$} & Identifying generalizations of cultures & $\begin{array}{l}\text { Materials that encourage the learners to voice up } \\
\text { their opinions and/or attitudes about aspects of } \\
\text { cultures including their own and the foreign } \\
\text { cultures. }\end{array}$ \\
\hline & Changing perspective & $\begin{array}{l}\text { Materials that push the learners to argue certain } \\
\text { cultural aspects, or call them to learn and change } \\
\text { their behavior for betterment particularly } \\
\text { through representations of foreign cultures. }\end{array}$ \\
\hline \multirow{3}{*}{$\begin{array}{l}\text { Interpreting and } \\
\text { relating cultural } \\
\text { elements }\end{array}$} & Identifying ethnocentric perspectives & $\begin{array}{l}\text { Materials that invite learners to focus on } \\
\text { particular cultural aspects in one culture whether } \\
\text { in their own or foreign culture representations. }\end{array}$ \\
\hline & Relating cultures and cultural phenomena & $\begin{array}{l}\text { Materials that ask learners to relate and compare } \\
\text { cultures to find out the similarities and } \\
\text { differences and consequently to learn reflecting } \\
\text { that in an improved cultural understanding }\end{array}$ \\
\hline & $\begin{array}{l}\text { Identifying and explaining causes of } \\
\text { misunderstandings }\end{array}$ & $\begin{array}{l}\text { Materials that request identifying areas of } \\
\text { potential misunderstandings and dysfunctions in } \\
\text { interaction and explaining them in accordance to } \\
\text { their own cultural contexts }\end{array}$ \\
\hline \multirow{3}{*}{$\begin{array}{l}\text { Discovery and } \\
\text { Intercultural } \\
\text { Interaction } \\
\text { elements }\end{array}$} & $\begin{array}{l}\text { Functioning as a mediator between } \\
\text { cultures and dealing with conflicting } \\
\text { situations }\end{array}$ & $\begin{array}{l}\text { Materials that ask learners to mediate between } \\
\text { cultures and/or to argue about conflicting issues } \\
\text { to find solutions and common grounds }\end{array}$ \\
\hline & Collecting information on cultures & $\begin{array}{l}\text { Materials that increase the learners' knowledge } \\
\text { through encouraging them to find information } \\
\text { about the cultural aspects from sources other } \\
\text { than the textbook }\end{array}$ \\
\hline & Applying one's abilities in interaction & $\begin{array}{l}\text { Material that request the learners to interact with } \\
\text { foreign culture representatives, with the use of all } \\
\text { their knowledge, attitudes and skills. }\end{array}$ \\
\hline
\end{tabular}

\section{Findings and Discussion}

This section is mainly for reporting the results of the analysis, and for consequently answering the research questions; it is concerned with the frequency occurrences of the intercultural elements in the content of the three intermediate textbooks. These elements can be distributed to the four intercultural elements in the analysis scheme as follows. 
Vol. 8, No. 4, 2019, E-ISSN: $2226-6348$ @ 2019 HRMARS

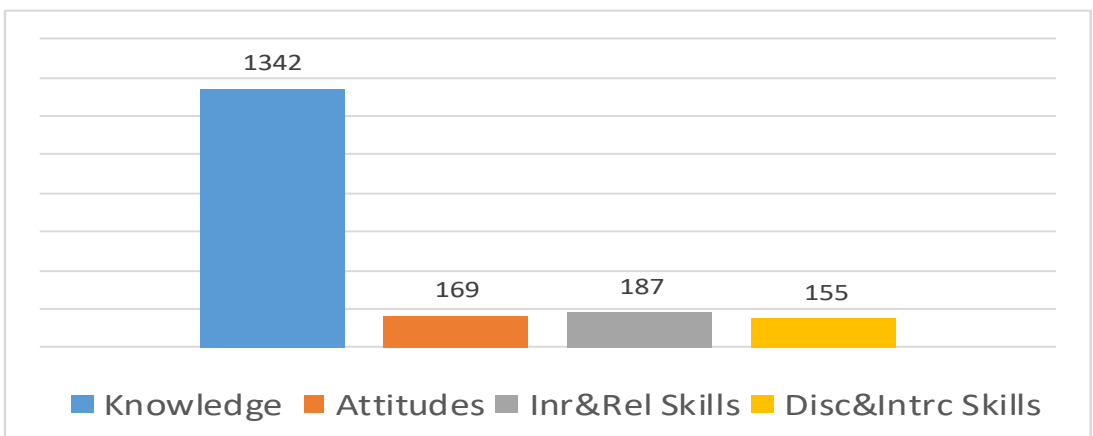

Figure (1) Intercultural elements in EFI intermediate textbooks

The distribution of the intercultural elements consists, as figure (1) shows, of a distinctive difference in proportions of which the highest-presented is knowledge-oriented materials.

\section{Knowledge}

As indicated in figure (2) most of the intercultural materials in the textbooks address "knowledge for cultures" elements which constitute approximately three quarters of the materials. The majority of the intercultural materials are knowledge-oriented. Knowledge is required to acquaint the learner with source and with other foreign cultures, but it is not expected to predominate with such a very large number of occurrences on cultures, local or foreign, as compared to the occurrences of the other intercultural elements. The intercultural content can also be distributed on the basis of the objectives in each element (see table 1 above). The "Knowledge of cultures" is the first category of elements in which the textbooks' authors are expected to provide information about the topics and the subjects included in the textbooks' lessons covering two objectives, factual information about cultures and information about understanding culture as a term.

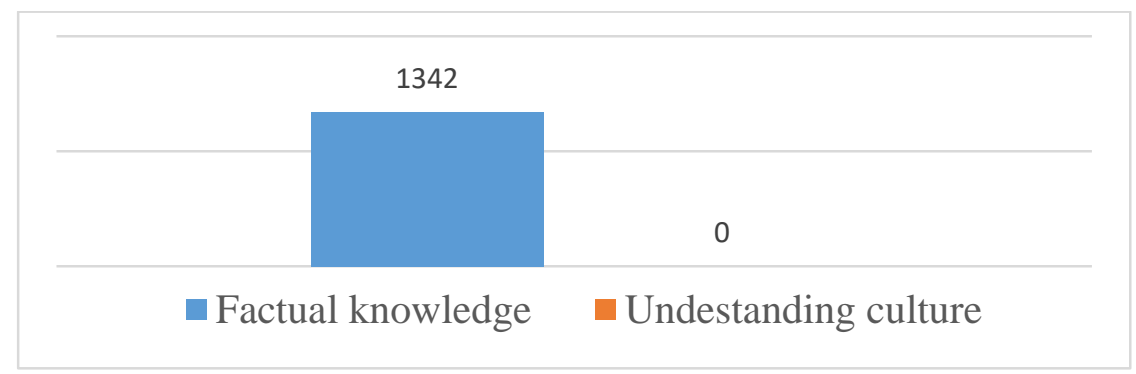

Figure (2) Objectives of "Knowledge of cultures" elements

As shown in Figure (2), knowledge of cultures is only presented in fact-stating texts and visuals. There are no representations that encourage students to understand culture per se as a term and what it may refer to. Knowledge alone can't be sufficient to promote interculturality especially when presented as a segregated collection of facts and not as integrated set with other-culture themes and meanings; that's why textbooks, as Hilliard (2014) proposes, should go more beyond presenting only cultural information to a deeper level of cultural discussions in activities so as to portray culture "as complex, multifaceted set of beliefs, traditions, and customs rather than as a rigid set of rules applicable to entire populations" (P: 246-47). As a result, EFI series of textbooks 
Vol. 8, No. 4, 2019, E-ISSN: 2226-6348 @ 2019 HRMARS

with the over-representation of factual information takes a proclivity of portraying cultures superficially and insensitively; This tendency can't allow the textbooks to be described as achieving the aim of empowering the learners' intercultural competence.
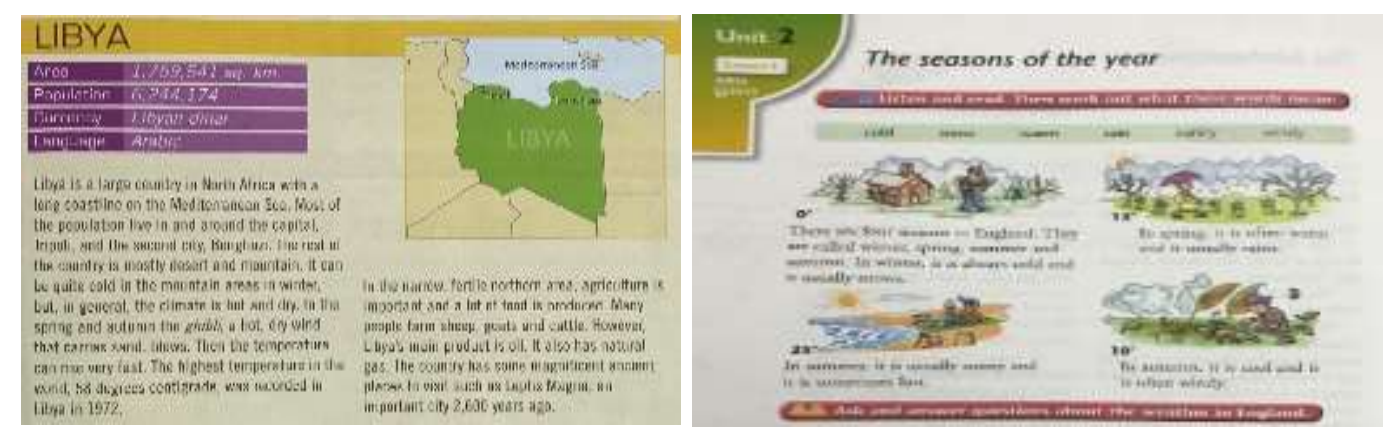

Figure (3) Examples of "Factual knowledge of cultures" objective

Knowledge-oriented materials of mainly fact-stating nature take various manifestations in the textbook series like telling stories or providing information about different subjects like schools, magazines, places, food, persons and so on. There are lessons about the seasons of the year, how to access the information at home or at another place, fact files about a ship, narrative information about countries like Libya, or the life of special kind of sea turtles.

\section{Attitudes}

The second category of intercultural elements is the "Attitude towards cultures" which comes third on the basis of the frequency occurrences (figure 1). Attitudes in the textbooks' intercultural materials, whether textual or visual, can motivate learners to voice up their opinions about their culture and the other cultures. Accordingly, learners can reinforce their intercultural competence with learning more tolerance, endurance of ambiguity, empathy and consequently more respect to otherness. These materials which ask or invite learners to express their thoughts curiously and open- mindedly in relation to a cultural issue particularly a foreign cultural phenomenon are opportunities that help learner get used to diversity and equality of cultures. Textbooks, for Wandel (2003), should contain materials that allow and provoke opinions and discussions on the part of students to negotiate meaning so as "to be able to tolerate and endure ambiguity" (P: 72). Principally, there are very few attitudinal items (see Figure 1) in the content of the EFI intermediate textbooks, which provide learners with opportunities for reflections and discussions about cultures; this means that the textbooks under investigation suffer from a serious lack of such opportunities and ultimately the Iraqi intermediate school learners do need a lot of exposition to materials that encompass elements with attitudes and self-expression. 
Vol. 8, No. 4, 2019, E-ISSN: 2226-6348 @ 2019 HRMARS

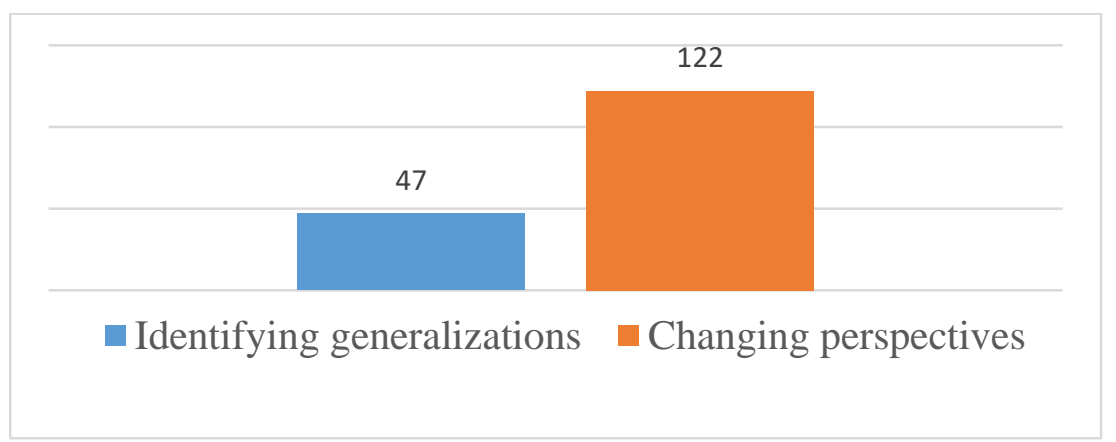

Figure (4) Objectives of "Attitudes towards cultures"

The first of the two objectives of the elements for attitudes towards cultures, "identifying generalizations", comes within the materials providing a knowledge-like information about certain culture, though this information is given in a form evolving reactions or attitudes. This information can be generalized to most cultures. This objective takes the lowest portion of the intercultural attitudinal materials in the textbooks.

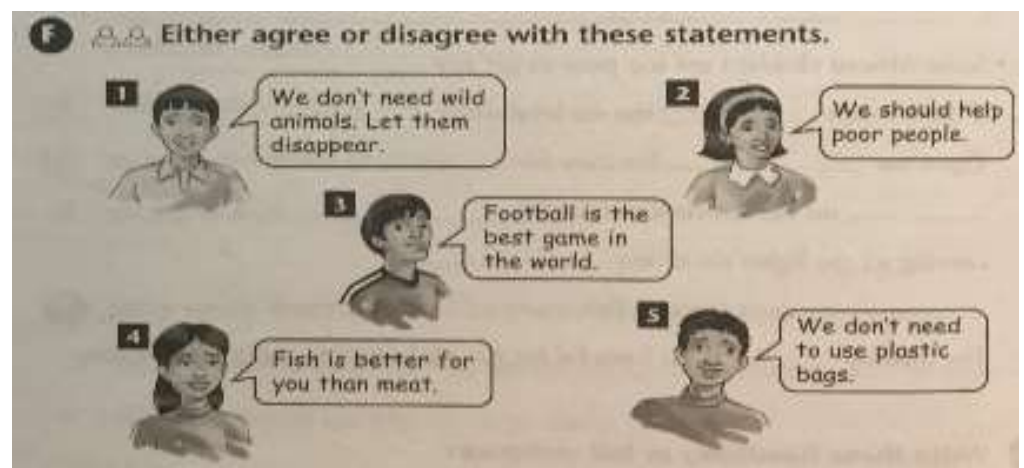

Figure (5) an example of "Identifying generalizations of cultures" objective

An example of this objective is a task (figure 5) in the second intermediate textbook asking the learner to agree or disagree about different phenomena like a need to get rid of all wild animals, Or considering football as the best of all sport games and so on. After discussion and endurance, different opinions can then share universality and a generalization in most, if not all, viewpoints. Still, students can, in such a way, practice empathy and endurance of the other's opinion in an intercultural learning space.

The second objective is "changing perspectives" constituting the other part of the originally lowrepresented elements of attitudes towards cultures. These intercultural representations encourage learners to have a better way of behaving or thinking. A change is expected to take place resulting from the learners' positive attitude towards a cultural aspect. According to Bennet's (1993) developmental model of cultural sensitivity, adaptation is one the advanced ethno-relative steps of an individual to integrate other cultures with his/her own. The steps start with ethnocentric stage (denial, defense, minimization) and ends off with ethno-relative stage (adaptation and integration) where changing perspectives is expected to occur. In the sociocultural theory of Vygotsky, integration (which can be related to the changing perspectives objective) is the second level of individual's development and learning; the first is interaction. 
Examples of representations of the second objective of attitudes are materials that encourage learners to keep listening, not to be wasteful, or save water and so on. Such materials are supposed to invite leaners to adapt their behaviors and perspectives in their lives to adopt new cultural orientations. Having this small number of attitudinal occurrences for changing the learners' perspectives, EFI textbooks again lack another effective intercultural factor in their learning materials, that can provide the intermediate school students in Iraq with opportunities for achieving one of the basic targets of Education in general and ELT in particular, which is leading learners to a perspective and behavioral betterment, most specifically in this case, to develop the learners' intercultural competence as a necessary characteristic of their future lives.

\section{Skills}

The scheme of analysis followed in this study encompasses two types of the intercultural elements representing skills. The first is "Interpreting and relating cultural elements" that allow the students to interpret, relate or compare cultures, including theirs with other cultures, and the second is "discovery and interactional elements" that motivate students to discover new knowledge that support them communicate successfully in a particular intercultural situation. Intercultural representations of skills train the students to improve their intercultural abilities. Skills of the two types also get low proportion in intermediate textbooks' intercultural content. The proportion of the first type "Interpreting and relating cultural elements" is higher than the second, with a sharp difference in occurrences with knowledge elements (see Figure 2 above). The objectives of this type of skills are three (figure 6 below). The second objective that is concerned with relating cultures and cultural phenomena gets the highest portion.

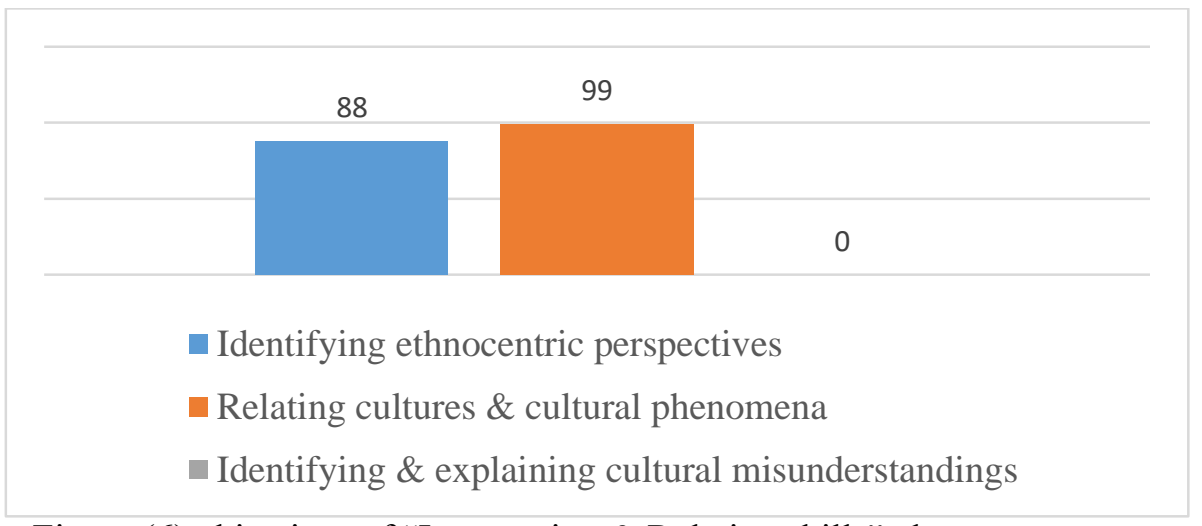

Figure (6) objectives of "Interpreting \& Relating skills" element

The materials of the first objective "Identifying ethnocentric perspectives" concentrate on a particular cultural point though it may be presented in a relational cultural situation of, for example, a dialogue or an interview. An example of this first objective is a dialogue between Muna, and Katie about Katie's visit to Thailand in her holiday. There was a lot of positive talk about the services, food, and cities of Thailand. In the visual demonstration there is a picture with magazines about Thailand. Another example is in the third intermediate textbook of a dialogue in a task pointing out how sightseeing and shopping is amazing in London. With such activities and tasks learners are exposed to particular cultural ethnocentric points of view usually about a foreign cultural aspect. Though presented in an ethnocentric way, these materials could be 
employed to provoke the learners' curiosity to interpret or relate the given ideas with their own cultural reality.

The second objective of interpreting and relating cultural elements is the one concerned with relating cultures and cultural phenomena. Intercultural material of this objective has a significant importance for the learners compared to the other objectives of the intercultural elements since it, as the title shows, encourages learners to make direct relations between cultures. According to Byram et al (2002), referring to Chichirdan's et al.(1998) thesis of the necessity to present materials in a critical approach to the learners, providing authentic materials in contrasting views with clear context will help learners to acquire skills of analysis required to promote their intercultural competence; therefore, it is advisable that "Materials from different origins with different perspectives should be used together to enable learners to compare and to analyze the materials critically. It is more important that learners acquire skills of analysis than factual information" (P: 24). Hence, the presentation of intercultural materials in a form of a relation (including comparison or contrast) between more than one cultures is more influential in learning than mere fact-stating materials of one culture.

Materials addressing this objective foster the intercultural competence as the learners would discover, while making relations, how cultures in the world are equal, share universalities, and are often complimentary or integrating one another, or how cultural phenomena can easily be transferable in this multicultural small-village globe.

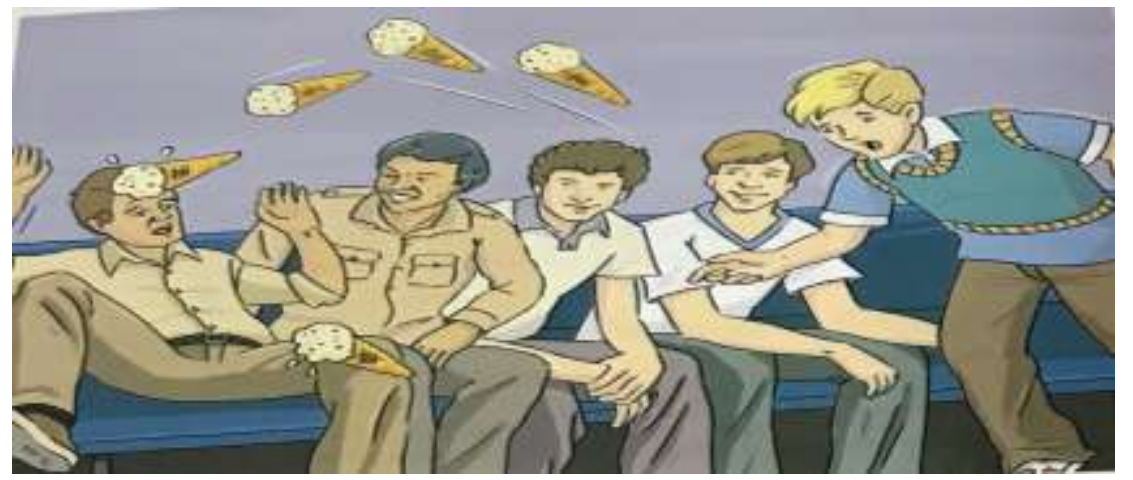

Figure (7) An example of "Relating cultures and cultural phenomena" objective

An example for making relations between cultures is in the second intermediate textbook, of a story about a group of guys of different cultures coming from various countries to the World Youth Camp in Australia. The story is presented in a series of complementary interactional material in many lessons along the units of the textbook with different titles. The main title of the story, Bob and Basim, comes in Unit one; but "Bob and Basim-the eggs" is in Unit two, "Bob and Basim-the ice cream" is in Unit three, "Bob and Basim-the ants" is in Unit five, "Bob and Basim-the basketball" is in Unit six, and "Bob and Basim - the medals" is in Unit seven. World cultures melt in a group of interactional intercultural situations where there is respect, support, and friendship in spite of the competition and prizes. This is a learning opportunity to the young learners in the second intermediate grade (age 12) to be motivated and also prepared to be intercultural citizens who are supposed to be interculturally-competent.

The second type of skills elements is the "discovery and interactional" which gets the least occurrences in the intercultural content. Due to the relative complexity of this type of skills 


\section{INTERNATIONAL JOURNAL OF ACADEMIC RESEARCH IN PROGRESSIVE EDUCATION AND}

DEVELOPMENT

Vol. 8, No. 4, 2019, E-ISSN: 2226-6348 @ 2019 HRMARS

resulting from higher level of requirements on the part of the textbook-writer, higher level of perception on the part of the learner, and high level of readiness on the part of the educational institution, it is much expected in the EFL context of Iraq that the proportion allotted to these elements in the learning materials of textbooks would be lower than other elements. Figure (8) shows the proportions of the objectives of the intercultural interactional elements of skills.

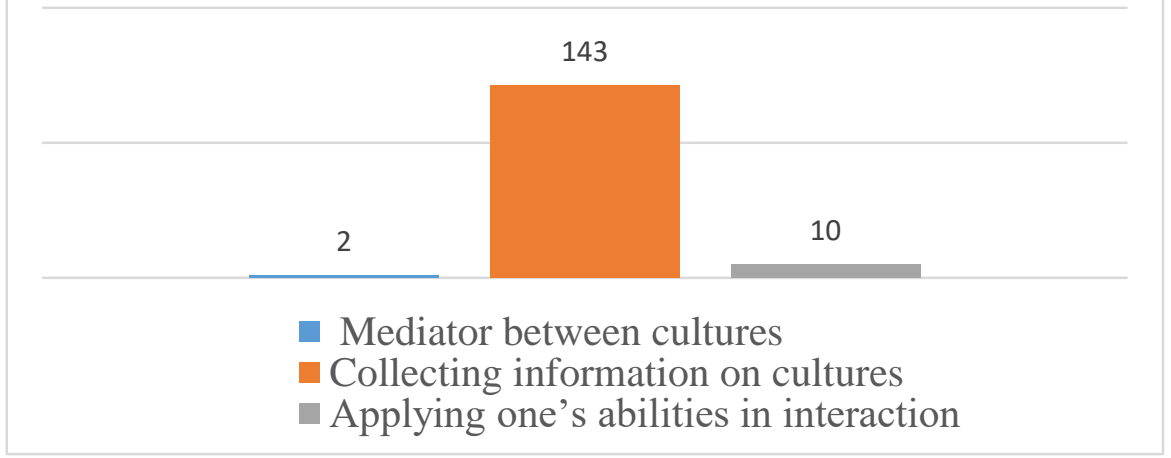

Figure (8) objectives of the "discovery and interactional elements" Intercultural skills in EFI intermediate textbooks

The first objective "Functioning as a mediator between cultures and dealing with conflict situations" is present in only two intercultural representations available in the third intermediate textbook. One of these representations is in the Activity Book, about Ibrahim's life story; he achieved his dream to mediate on his rural environment featured with breeding animals to his friend in another country (another culture) to become later a zoologist studying this environment in a European university.

The highest frequency of occurrence of the basically-low-represented intercultural interactional elements has been gained by the second objective which is "Collecting information on cultures". The information in this objective is gathered by the learners themselves; it differs from the first intercultural elements in the scheme of analysis related to "knowledge on cultures" in which information is provided directly by textbooks' authors. In this objective, the students are required to discover new information from resources other than the textbooks. It may partly imply finding more facts about culturally-embedded subjects.

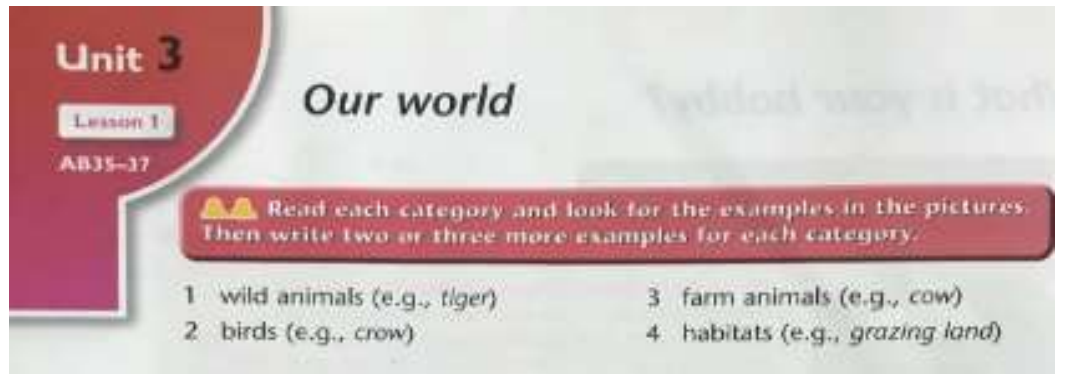

Figure (9) an example of "Collecting information on cultures" objective

An example of this objective, as seen in the figure (9), is giving an idea for categories of animals; the student is asked to write about other animals belonging to these categories in our world. The third objective in the second type of skills, which is "Applying one's abilities in interaction", refers to the individual's employment of all interactional abilities including the previous 
accumulated knowledge, attitudes and skills in a successful communicative intercultural context. Most of the intercultural representations of this objective are in Unit six in the first intermediate textbook. This unit is about a visit of an Iraqi boy Fuad to Japan to meet his Japanese friend Yuki. Fuad has to employ all of his interactional abilities to communicate with his new friend and the family in a country which he visits for the first time, and whose culture is different from his own. The situations in this example could be an actual illustration of one of Byram's (1997) meanings given to the concept of "intercultural communication" particularly when English as a Lingua Franca is expected to be used, as this is "an interaction between people of different languages and countries where the language used is a lingua franca" (P: 22), close to Jandt (2018) understanding of this concept as the interaction that takes place " between people and groups of diverse culture, subculture, or subgroup identifications" (P: 1072). This particular unit in the first intermediate textbook is an intercultural-rich unit. The very few intercultural interactional representations of this objective, which are mainly concentrated in one unit of a textbook, gives an impression of the scattered and unbalanced distribution of the intercultural elements through the textbooks of the series.

The intercultural elements representing the two types of skills and their objectives are underrepresented due to the small proportion of occurrences they record in the textbooks' content. It can then be said that there is also a lack of another influential intercultural element related to the skills' representations in the intercultural materials of the intermediate textbooks as opposite to an abundance of mere fact-stating materials dominating these textbooks.

\section{Discussion}

Findings show that there is a very sharp difference of occurrences in presenting the materials demonstrating the four intercultural elements in favor of the greatly-dominating knowledge about cultures given in a bulk of fact-stating information in the written texts and the visuals of the textbooks under study. This knowledge is either directly provided by the textbook writers or obtained by the learners themselves. The majority of the intercultural materials in the textbooks address "knowledge for cultures" elements encompassing more than three quarters of the materials. The occurrences of the remaining elements (attitudes and skills) constitute less than a quarter of the materials; therefore, the learning space for these two elements essential for interculturality is left narrow for the learners. Such a very sharp difference in proportions reveals an imbalanced distribution of intercultural representations in the materials of EFI intermediate textbooks, reflecting a mismatch with the global EFL objective of developing intercultural competence.

Knowledge alone is not sufficient to promote intercultural competence, especially when presented as a segregated collection of facts and not as an integrated set with other-culture themes and meanings. Findings of the current study seem to be compatible in integrating intercultural representations in ELT textbooks used in Norway for grades 8,9, and 10. Lund (2006) concluded that the materials of these textbooks are dominated with fact-oriented presentations of historical events and of descriptions for peripheral cultural phenomena, and they then attach "very little importance to intercultural issues" (p. 290). According to Hilliard (2014) textbooks' writers and publishers should account for the "depth of cultural information" (P: 238) that can provoke analysis, discussion and meaning-search and allow students to "know a number of 
different cultural outlooks and perspectives" (Wandel, 2003: 73). However, the current study found that the three EFI intermediate textbooks takes a proclivity of portraying cultures superficially or peripherally due to the dominating fact-stating feature with only few representations illustrating relations, comparisons or contrast between cultures; as such, they can't support achieving the global aim of empowering the learners' intercultural competence.

Materials with attitude intercultural elements provide learners with opportunities reinforcing their self-confidence to say out their views open-mindedly in an intercultural communicative atmosphere without any prior disbelief or disrespect to other cultures. The small proportion of representations of the "Attitudes towards cultures" elements in EFI intermediate textbooks indicates that these textbooks suffer from a lack of such opportunities for learners. The Iraqi intermediate school learners will eventually miss chances for a perspectives' change or adaptation (Bennet, 1993) potentially resulting from their positive attitude towards an intercultural aspect in the materials. Accordingly, EFI textbooks again lack another effective intercultural factor in their learning materials which can lead learners to a perspective and behavioral betterment, most specifically, to develop their intercultural competence as a necessary characteristic of their future lives as intercultural citizens.

Materials developing the intercultural skills train learners to acquire tolerance and adaptation to diversity. They are also underrepresented in EFI intermediate textbooks. The first type of these materials are intercultural representations that emphasize comparisons and relations between cultures reinforcing the learners' critical reflections to find similarities or shared meanings, as "Once learners can develop an understanding of the shared meanings of values in their home and the target culture, they can reduce their ethnocentrism and develop respect and empathy towards people of the target culture" (Ho, 2009:71). The low proportion of this element in the EFI intermediate textbooks reveals a need for more learning space to train the Iraqi students to increase their cultural relativism and decrease ethnocentrism and to ultimately understand that "Each culture has different values and none of the values in one culture is better than the others in another culture" (ibid). The second type of these materials are intercultural representations that invite learners to employ their knowledge, attitudes, and skills to themselves discover interactional elements in any intercultural communication. This kind of materials is least represented in EFI intermediate textbooks. But the highest frequencies of occurrence of this type of skills have been gained by the second objective which is "Collecting information on cultures". These occurrences may also increase the abundance of the mere fact-stating materials dominating the textbooks. Therefore, the three EFI intermediate textbooks can also be described as lacking intercultural materials for skills to train learners on interculturality.

\section{Conclusion and Implications}

Based on the frequency occurrences of the intercultural elements (knowledge, attitude, and skills) in the texts and the visuals in the three EFI intermediate textbooks, a sharp difference is detected in favor of high domination of knowledge-oriented materials with fact-stating nature. On the contrary, there are low proportions for attitudes' representations as well as skills' representations. It can accordingly be concluded that these textbooks are characterized with unbalanced distribution of intercultural representations in their materials. 
Vol. 8, No. 4, 2019, E-ISSN: $2226-6348$ @ 2019 HRMARS

This imbalanced distribution of intercultural representations with such an abundance of knowledge-directed materials, together with far less representations for attitudes and skills, deprive the Iraqi intermediate students from learning opportunities where they can voice their opinions about cultures, change perspectives, and be trained for their role as intercultural citizens with basic traits of intercultural abilities like empathy, tolerance, and respect of otherness. As such, the textbooks under study can be portrayed as interculturally-weak, and do not follow the intercultural approach in language teaching where materials are not introduced as segregated, mere fact-stating texts and visuals, but as self-expressing and comparisonmotivating materials. Therefore, it can also be concluded that the EFI intermediate textbooks series fails to account for developing the learners' intercultural competence.

Since accounting for interculturality in EFL textbooks is currently one of the global objectives of ELT, this paper has important implications for Ministry of Education in Iraq, and the textbooks' writers, developers and publishers in the ELT Iraqi context to maintain a greater emphasis on intercultural materials to make this context compatible with the recent developments in the field.

\section{Corresponding Author}

Dr. Lilliati Ismail is a senior lecturer at the Faculty of Educational Studies, Universiti Putra Malaysia. She holds a PhD in TESL. Her research interests include grammar instruction and taskbased language teaching.

\section{References}

Ahmed, U. J. (2010) Documentary Research Method: New Dimensions, Indus Journal of Management \& Social Sciences, (1):1-14.

Al-Akraa, S. (2013). Teaching English in Iraq: An Analysis of EFL Textbook. (Unpublished MA Thesis in TESOL). College of Arts and Humanities, University of Central Florida Orlando, Florida.

Al-Obaidi, L. A. (2015). The Cultural Aspects in the English Textbook "Iraq Opportunities" for Intermediate Stages (Unpublished MA Thesis). Faculty of Arts and Sciences. Middle East University. Turkey.

Bennet, M. J. (1993). Toward Ethnorelativism: A development model of intercultural sensitivity. In Paige (Ed). Education for Intercultural Experience (pp:27-71). Yarmouth, Me: Intercultural Press

Byram, M. (1997). Teaching and assessing intercultural communicative competence. Multilingual Matters.

Byram, M., Gribkova, B., \& Starkey, H. (2002). Developing the intercultural dimension in language teaching. A practical introduction for teachers. Strasbourg: Council of Europe.

Castro, P., Sercu, L. \& Garcia, M. D. C. M. (2004). Integrating language-and-culture teaching: an investigation of Spanish teachers' perceptions of the objectives of foreign language education. Intercultural Education 15(1), 91-104.

Common European Framework of Reference for Languages: Learning, Teaching, Assessment. Retrieved from http://www.coe.int/t/dg4/linguistic/cadre1_en.asp

Ezzy, D. (2002). Qualitative analysis: Routledge.

García, M. D. C. M. (2005). International and intercultural issues in English teaching textbooks: The case of Spain. Intercultural education, 16(1), 57-68. 
INTERNATIONAL JOURNAL OF ACADEMIC RESEARCH IN PROGRESSIVE EDUCATION AND DEVELOPMENT

Vol. 8, No. 4, 2019, E-ISSN: 2226-6348 @ 2019 HRMARS

Grant, N. (1987). Making the most of your textbook: Longman London.

Guilherme, M. (2002) Critical Citizens for an Intercultural World Foreign Language Education as Cultural Politics. Multilingual Matters Ltd.

Hatoss, A. (2004). A model for evaluating textbooks. Babel, 39(2), 25-32.

Hillard, A. D. (2014) A Critical Examination of Representation and Culture in Four English Language Textbooks. Language Education in Asia.5 (2). 238-249

Ho, S. T. K. (2009). Addressing culture in EFL classrooms: The challenge of shifting from a traditional to an intercultural stance. Electronic journal of foreign language teaching, 6(1), 63-76.

Kramsch, C. (2013). Culture in Foreign Language Teaching. Iranian Journal of Language Teaching Research, 1(1), 57 - 78.

Labuschagne, A. (2003). Qualitative research - Airy fairy or fundamental? The Qualitative Report, 8(1). Retrieved from http://www.nova.edu/ssss/QR/QR8-1/

Lantolf, J. P., Thorne, S. L. \& Poehner, M. E. (2015) Sociocultural theory and second language development. In Patton \& Williams (eds) Theories in second language acquisition: An Introduction (pp: 207-227). NY: Taylor \& Francis

Larzén-Ostermark, E. (2008). The intercultural dimension in EFL-teaching: A study of conceptions among Finland-Swedish comprehensive school teachers. Scandinavian Journal of Educational Research, 52(5), 527-547.

Lund, R. (2006): Questions of Culture and Context in English Language Textbook: A Study of Textbooks for the Teaching of English in Norway, (Unpublished Doctoral Dissertation), University of Bergen, Norway.

McCulloch, G. (2004) Documentary research in education, history, and the social sciences. London: Routledge.

McKay, S. L. (2002). Teaching English as an International Language: Rethinking Goals and Perspectives: New York: Oxford University Press.

Merriam, S. B. (2009). Qualitative Research: A Guide to Design and Implementation. San Francisco: John Wiley \& Sons Inc.

Reid, E. (2015). Techniques developing intercultural communicative competences in English language lessons. Social and Behavioral Sciences, 186, 939-943.

Shrum, J. L., \& Glisan, E. W. (2009). Teacher's handbook: Contextualized language instructions. Florence, Kentucky: Heinle Cengage Learning.

Tözün, Z. (2012).) Global English Language and Culture Teaching in TRNC Secondary EFL Classroom: Teachers' Perceptions and Textbooks (Master Thesis), Eastern Mediterranean University.

Vygotsky, L. S. (1978). Mind in society: The development of higher psychological processes. Harvard University Press.

Wandel, R. (2003). Teaching India in the EFL-Classroom: A cultural or an intercultural approach? In: Byram, M. \& Grundy, P. (Eds.). Context and culture in language teaching and learning. (pp:72-80), Clevedon: Multilingual Matters.

Zhang, Y., \& Wildemuth, B. M. (2009). Qualitative analysis of content, in B. M. Wildemuth, (Ed.), Applications of Social Research Methods to Questions in Information and Library Science, (308-320). London: Libraries Unlimited. 


\section{INTERNATIONAL JOURNAL OF ACADEMIC RESEARCH IN PROGRESSIVE EDUCATION AND}

DEVELOPMENT

Vol. 8, No. 4, 2019, E-ISSN: 2226-6348 @ 2019 HRMARS

Okoye, I., Ugochukwu, N. J., Chidoziem, A. M. F. (2018). Forestalling Ingenious Approach to Financial Reporting in Post IFRS Regime in Dangote Cement Company Nigeria PLC, International Journal of Academic Research in Accounting, Finance and Management Sciences 8 (2): 259-271 